\title{
AAA Consumer Arbitration
}

\author{
Christopher R. Drahozal
}

Drahozal, Christopher R., AAA Consumer Arbitration (January 23, 2014). Beyond Elite Law: Access to Civil Justice for Americans of Average Means (Samuel Estreicher \& Joy Radice eds. Cambridge University Press Forthcoming). Available at SSRN: http://ssrn.com/abstract=2446160

\section{Abstract:}

This chapter has provided an overview of consumer arbitrations administered by the American Arbitration Association, the largest administrator of consumer arbitrations. It does not, of course, purport to resolve the ongoing debate over arbitration and access to justice. A consumer's incentive to bring a claim (and an attorneys' incentive to take a case) depend on the costs of the process and the expected outcome in the forum. With the recent amendments to its consumer arbitration rules, the AAA reduced the cost to consumers of bringing claims in arbitration, both by lowering the upfront fees and by largely precluding reallocation of fees to consumers in the award. The expected outcome in arbitration (in particular, relative to the expected outcome in court) presents a much more difficult question because limits to available data preclude comparison of similarly-situated complainants. More research remains to be done. 